\title{
Role of Central Bank Independence in Banking and Financial Stability Ensuring
}

\author{
http://doi.org/10.21272/fmir.4(2).115-121.2020
}

Victoria Dudchenko, ORCID: https://orcid.org/0000-0002-0054-8362

Associate Professor, the department of international economic relationships, Sumy State University, Sumy, Ukraine

\begin{abstract}
This paper is devoted to defining the role of the central bank in ensuring banking and financial stability. The main purpose of the study is to assess the direction and strength of the impact of central bank independence in terms of its individual aspects on the parameters of banking and financial stability for different groups of countries. Systematization of literature sources and the results of existing empirical research has shown that the expected effects of increasing the independence of the central bank are to improve banking and financial stability. For the study, a sample of statistical data for 10 developed and 10 developing countries for the period 1991-2012 was formed. The methodological basis of the study were the tools of panel regression modeling with fixed effects with Stata software use. The article presents the results of empirical analysis, which showed that the independence of the central bank is an important factor in ensuring banking stability. At the same time, the impact on financial stability has not been conclusively confirmed. The study empirically confirms and theoretically proves that the stage of development of the country determines the strength of such influence. Thus, developed countries generally show closer links between central bank independence and banking and financial stability, which in most cases are directly dependent, while developing countries have less lasting effects. The results of the analysis of the links between certain aspects of central bank independence and the level of banking and financial stability are of great practical value. The results of the study create a scientific basis for substantiating the sequence of actions aimed at strengthening the independence of the central bank. Thus, in developing countries, the focus should be on defining and prioritizing central bank goals, while developed countries should take a deeper approach to this issue and ensure the independence of monetary policy and financial independence of the central bank.
\end{abstract}

Keywords: central bank, independence, banking stability, financial stability, Z-score, non-performing loans, capitalization, developed countries, developing countries, panel data.

JEL Classification D53, E58, E63, G21, O16.

Cite as: Dudchenko, V. (2020). Role of Central Bank Independence in Banking and Financial Stability Ensuring. Financial Markets, Institutions and Risks, 4 (2), 115-121. http://doi.org/10.21272/fmir.4(2).115$\underline{121.2020 .}$.

(C) The Author, 2020. This article is published with open access at Sumy State University.

\section{Introduction}

The growing risks of instability of the global and national economies, the development of their financialization, the strengthening of capital movements and the emergence of new forms of financial cooperation necessitate increased efficiency of regulatory policy in the financial sector. The negative experience of political and economic crises testifies to the priority of ensuring the independence of the central bank as the main prerequisite for its effective operation in regulating the banking system. World practice has shown that the independence of the central bank has a close direct relationship not only with price stability, but also with the stability of the financial system as a whole, increasing the ability of the state to withstand crisis processes. At the same time, it is important not only to determine the relationship between the independence of the central bank and the level of banking and financial stability, but also to justify the channels of influence of the central bank on the stabilization of the banking system. At the same time, it is expected to obtain various effects depending on the initial level of independence of the central bank, its dynamics and macroeconomic conditions of the country's development. 


\section{Literature review}

Ensuring the trend of increasing the quality of central bank governance in terms of maintaining price stability remain in the spotlight for a long period of time. Central bank reforms have raised expectations about the positive impact of central bank independence on this task (Crowe and Meade, 2007). Cristea and Lupua (2014) analyze the significant role of financial stability among the goals of the central bank. At the same time, there is a conflict of goals between price stability and financial stability. In this regard, it is a subject of scientific interest to study the impact of central bank independence on price and financial stability in terms of assessing the possibility of achieving them simultaneously. The results of the assessment of the impact of central bank independence on the stability of banks and the banking system, measured by the level of systemic risk obtained by Andrieș and Podpiera (2018), showed that increasing the independence of central banks is associated with a decrease in the level of systemic risk. At the same time, countries with a higher level of development and a more competitive banking system show a larger effect. Sheppard (2008) justifies that the independence of the central bank has different effects for developed and developing countries. Moreover, each central bank has its own specifics, which determine the features of the impact of its independence on the achievement of certain goals. On the other hand, studies conducted on a sample of developed and developing countries have shown that increasing central bank independence increases the volatility of the securities market proportionally. These effects are observed for all components of central bank independence (Afshari and Daraei, 2018). Balls et al (2018) not only revealed the differences of effects obtained due to central banks' independence growth in advanced and developing economies, but also define the prospects of central banks independence development taking into account financial crisis consequences influence. Based on this, we determine that in the face of continuing threats of financial crises, the study of the relationship between central bank independence and the level of banking and financial stability in the context of the formation of preventive anti-crisis policy of the central bank becomes relevant.

\section{Methodology and Results}

Set of factor variables was formed based on the central bank's independence index developed by Cukierman et al. (1992). It is based on the principle of prioritizing price stability for the central bank and, accordingly, its ability to make any decisions aimed at its observance, even in the event of a conflict of interest with other authorities and other political goals. This index allows measuring the following aspects to be considered in the evaluation process: 1) peculiarities of appointment and dismissal of the chairman of the central bank, term of his powers; 2) policy aimed at resolving the conflict of interests between the central bank and the executive, the relationship of the central bank with the budget process; 3) main goals of the central bank; 4) restrictions on the possibility of direct and indirect lending to the public sector by the central bank. A database generated by Garriga A. C. (2016) containing the following variables was used for the calculations:

$>\quad$ CBI - total value of central bank's independence index calculated accordingly to Cukierman et al. (1992) methodology;

$$
\begin{aligned}
& >\quad \text { CBI_CEO - value of sub-index of central bank chief executive officer independence; } \\
& >\quad \text { CBI_Goal - value of sub-index of central bank goals definition (price stability priority); } \\
& >\quad \text { CBI_Policy - value of sub-index of central bank's independence in forming of their monetary policy; } \\
& >\quad \text { CBI_Lending - value of sub-index of government lending limitations. }
\end{aligned}
$$

Banking and financial stability indicators were selected from the The World Bank Global Financial Development database. There are 3 banking stability indicators:

$$
\begin{aligned}
& \text { Z-score - bank Z-score, indicator of the probability of default of a country's banking system; } \\
& \text { Non-performing loans - bank non-performing loans to gross loans, \%); } \\
& \text { Capitalization - bank regulatory capital to risk-weighted assets, \%. }
\end{aligned}
$$

To measure financial stability the indicator of Stock price volatility (the average of the 360-day volatility of the national stock market index) was chosen.

In addition, a list of control variables was formed to build econometric models for assessing the impact of central bank independence on financial and banking stability: 
Concentration - bank concentration measured as a ratio of three largest banks data to all banks data, \%

Debt - total value of outstanding international debt issues both public and private, as a share of GDP, $\%$.

GDP - annual value of GDP growth, \%.

Given the low variability of the level of independence of the central bank within one country, it is advisable to conduct empirical calculations on the basis of panel data. For this purpose, a statistical sample of data for 20 countries of the world for the period 1991-2012 was formed. The selected countries can be conditionally divided into 2 groups: developed countries (United States, Canada, United Kingdom, Ireland, Netherlands, Belgium, France, Switzerland, Spain, Germany) and developing countries (Ukraine, Latvia, Lithuania, Estonia, Poland, Hungary, Czech Republic, Slovak Republic, Bulgaria, Romania). In the next stages, calculations will be made both for the general sample of countries and within certain groups. This will assess the impact of the country's development stage on the use of the central bank's potential for independence in ensuring financial and banking stability. Panel regression modeling tools using Stat software were selected for assessment. Therefore, at the first stage we summarize the descriptive statistics on the selected factor, dependent and control variables (Table 1). These data indicate a number of differences in the summarized values of the study variables for the two groups of countries. Thus, developed countries have a higher average level of central bank independence index and lower average its volatility compared to developing countries. In terms of individual sub-indices, this trend is observed for almost all indicators, except for government lending limits, which show the best volatility and mean values in developing countries.

Table 1 . The summarizing statistics on research variables within developed and developing countries

\begin{tabular}{|l|c|c|c|c|c|c|c|c|c|c|}
\hline \multirow{2}{*}{ Variable } & \multicolumn{4}{|c|}{ Developed countries } & \multicolumn{4}{c|}{ Developing countries } \\
\cline { 2 - 12 } & Obs & Std. Dev. & Mean & Min & Max & Obs & Std. Dev. & Mean & Min & Max \\
\hline CBI & 220 & 2.486464 & 0.7423753 & 0.533 & 3.183 & 214 & 2.83029 & 0.63285 & 1.183 & 3.517 \\
\hline CBI_CEO & 220 & 0.5789409 & 0.1213984 & 0.25 & 0.83 & 214 & 0.676626 & 0.1197733 & 0.25 & 0.77 \\
\hline CBI_Goal & 220 & 0.5290909 & 0.2418896 & 0 & 1 & 214 & 0.689719 & 0.1507008 & 0.4 & 1 \\
\hline CBI_Policy & 220 & 0.6185727 & 0.3859866 & 0 & 1 & 214 & 0.767504 & 0.2094364 & 0.282 & 1 \\
\hline CBI_Lending & 220 & 0.7596 & 0.2795528 & 0.166 & 1 & 214 & 0.696303 & 0.3555288 & 0 & 1 \\
\hline Z-score & 170 & 14.00728 & 6.847651 & 0.0557 & 38.595 & 170 & 7.70914 & 3.536214 & 1.013 & 18.57 \\
\hline $\begin{array}{l}\text { Non-performing } \\
\text { loans }\end{array}$ & 147 & 2.786846 & 2.839029 & 0.3 & 24.987 & 135 & 8.5012 & 8.132887 & 0.2 & 35.8 \\
\hline Capitalization & 149 & 13.13496 & 1.915185 & 10.2 & 19.304 & 137 & 15.3406 & 4.791875 & 6.6 & 41.8 \\
\hline $\begin{array}{l}\text { Stock price } \\
\text { volatility }\end{array}$ & 213 & 19.08177 & 7.351045 & 7.822 & 45.658 & 130 & 24.4702 & 9.69059 & 10.37 & 57.07 \\
\hline Concentration & 170 & 66.4774 & 18.95209 & 20.18 & 100 & 170 & 65.3986 & 16.77651 & 26.98 & 100 \\
\hline Debt & 217 & 43.71932 & 38.94331 & 2.345 & 223.21 & 178 & 9.96733 & 9.226201 & 0.669 & 39.77 \\
\hline GDP & 210 & 1.588097 & 2.324949 & -6.334 & 9.7911 & 200 & 3.40706 & 5.579287 & -22.5 & 13.08 \\
\hline
\end{tabular}

Source: compiled by author.

On the other hand, the stability indicators of the banking and financial system reflect higher risks of instability for developing countries compared to developed countries. At the same time, the values of control variables indicate the prospects for a positive impact of macroeconomic conditions on banking and financial stability in developing countries. So, we move on to the next step, which is to determine the relationships between the studied variables. At this stage, the model specification should be determined. The Hausman test showed that a regression model with fixed effects is more adequate for the given statistics. The results of the assessment of the generalized for developed and developing countries, the impact of central bank independence on banking stability, measured by the bank Z-score indicator, are presented in table 2 .

Table 2. The results of multiple panel regression modeling of the impact of central banks' independence on bank Z-score

\begin{tabular}{|l|c|c|c|c|c|c|}
\hline \multicolumn{1}{|c|}{ Variable } & Coef. & Std. Err. & $\mathrm{t}$ & $\mathrm{P}>|\mathrm{t}|$ & Lowest 95\% & Highest 95\% \\
\hline CBI & $1.079535^{* *}$ & 0.479194 & 2.25 & 0.025 & 0.1366626 & 2.022407 \\
\hline Concentration & -0.0045538 & 0.0162917 & -0.28 & 0.780 & -0.0366097 & 0.027502 \\
\hline Debt & $-0.0284821 * * *$ & 0.0076333 & -3.73 & 0.000 & -0.0435016 & -0.0134627 \\
\hline GDP & -0.0047939 & 0.0446411 & -0.11 & 0.915 & -0.0926306 & 0.0830428 \\
\hline Constant & $9.058376^{* * *}$ & 1.85529 & 4.88 & 0.000 & 5.407868 & 12.70888 \\
\hline
\end{tabular}

Notes: level of statistical significance at one of the confidence intervals: $* * *-99 \%, * *-95 \%,{ }_{-}{ }_{-} 90 \%$.

Source: compiled by author. 
This table shows that the growth of central bank independence has a positive impact on maintaining banking stability, which is statistically significant. It should be noted that among the control variables there is a statistically significant effect only for the parameter of international public debt, the increase in the relative level of which causes a reduction in the stability of the banking system. At the same time, it is important to detail the results obtained. For this purpose, additional calculations were performed to assess the impact of the central bank's independence index and its sub-indices in terms of the two groups of countries studied, the results of which are shown in table. 3. Additional calculations show that in developed countries the impact of central bank independence on bank Z-score is positive and statistically significant, and its quantitative level is significantly higher than previous calculations. At the same time, in developing countries, the level of bank Zscore is not influenced by central bank independence.

Table 3. The results of multiple panel regression modeling of the impact of central banks' independence on bank Z-score within developed and developing countries

\begin{tabular}{|l|c|c|c|c|c|c|c|c|}
\hline \multirow{2}{*}{ Variable } & \multicolumn{4}{|c|}{ Developed countries } & \multicolumn{4}{c|}{ Developing countries } \\
\cline { 2 - 9 } & Coef. & Std. Err. & $\mathrm{t}$ & $\mathrm{P}>|\mathrm{t}|$ & Coef. & Std. Err. & $\mathrm{t}$ & $\mathrm{P}>|\mathrm{t}|$ \\
\hline CBI & $2.407289^{* *}$ & 0.9526951 & 2.53 & 0.013 & 1427816 & .4169192 & 0.34 & 0.732 \\
\hline CBI_CEO & 1.105872 & 6.486793 & 0.17 & 0.865 & -3.07171 & 2.46507 & -1.25 & 0.215 \\
\hline CBI_Goal & 2.016903 & 1.588888 & 1.27 & 0.206 & $2.656257 *$ & 1.587554 & 1.67 & 0.096 \\
\hline CBI_Policy & $4.802229 * *$ & 2.10887 & 2.28 & 0.024 & 1.185159 & 1.357216 & 0.87 & 0.384 \\
\hline CBI_Lending & 3.213729 & 2.152866 & 1.49 & 0.138 & -0.1354016 & 0.6233826 & -0.22 & 0.828 \\
\hline
\end{tabular}

Notes: level of statistical significance at one of the confidence intervals: $* * *-99 \%, * *-95 \%, *-90 \%$. Source: compiled by author.

At the same time, the results obtained in the study of the impact of central bank independence sub-indices are interesting. We can conclude that for developed countries the most important stimulus for Z-score growth is the independence of the central bank in choosing monetary policy instruments, while for developed countries it is important to define in legislation the priority of price stability among the goals of the central bank. The next important indicator of banking stability is banks 'non-performing loans. According to Table 4, the growth of central bank independence provides a significant reduction in the level of non-performing loans in the banking system. At the same time, GDP growth is a factor that stimulates the improvement of the structure of banks' loan portfolios, while the concentration of the banking system and external debt, on the contrary, worsen the quality of loans in the assets of commercial banks and, accordingly, threaten banking stability.

Table 4. The results of multiple panel regression modeling of the impact of central banks' independence on banks' non-performing loans

\begin{tabular}{|l|c|c|c|c|c|c|}
\hline Variable & Coef. & Std. Err. & $\mathrm{t}$ & $\mathrm{P}>|\mathrm{t}|$ & Lowest 95\% & Highest 95\% \\
\hline CBI & $-3.185853^{* *}$ & 1.3657 & -2.33 & 0.020 & -5.875241 & -0.4964643 \\
\hline Concentration & $0.1221159^{* * *}$ & 0.0345 & 3.54 & 0.000 & 0.0541247 & 0.190107 \\
\hline Debt & $0.0340718^{* *}$ & 0.0139057 & 2.45 & 0.015 & 0.0066881 & 0.0614555 \\
\hline GDP & $-0.3600594^{* * *}$ & 0.0814026 & -4.42 & 0.000 & -0.5203604 & -0.1997584 \\
\hline Constant & 6.558788 & 4.648583 & 1.41 & 0.159 & -2.595377 & 15.71295 \\
\hline
\end{tabular}

Notes: level of statistical significance at one of the confidence intervals: $* * *-99 \%, * *-95 \%, *-90 \%$.

Source: compiled by author.

The results obtained at the next stage of the study (Table 5) show that in developing countries, the independence of the central bank does not have a significant impact on the level of non-performing loans. At the same time, the experience of developed countries shows that the independence of the central bank is an important factor limiting the level of non-performing loans both at the index level and in setting central bank goals and restrictions on government lending. At the same time, the independence of the CEO of the central bank, on the contrary, is a factor that leads to an increase in non-performing loans. 
Table 5. The results of multiple panel regression modeling of the impact of central banks' independence on banks' non-performing loans within developed and developing countries

\begin{tabular}{|l|c|c|c|c|c|c|c|c|}
\hline \multirow{2}{*}{ Variable } & \multicolumn{4}{|c|}{ Developed countries } & \multicolumn{4}{c|}{ Developing countries } \\
\cline { 2 - 9 } & Coef. & Std. Err. & $\mathrm{t}$ & $\mathrm{P}>|\mathrm{t}|$ & Coef. & Std. Err. & $\mathrm{t}$ & $\mathrm{P}>|\mathrm{t}|$ \\
\hline CBI & $-3.736438^{* * *}$ & 1.198663 & -3.12 & 0.002 & -2.207615 & 2.131109 & -1.04 & 0.302 \\
\hline CBI_CEO & $19.49897 * * *$ & 5.882204 & 3.31 & 0.001 & 13.53035 & 11.65434 & 1.16 & 0.248 \\
\hline CBI_Goal & $-3.873982^{* * *}$ & 1.225142 & -3.16 & 0.002 & 7.156109 & 7.303687 & 0.98 & 0.329 \\
\hline CBI_Policy & -12.33771 & 16.23858 & -0.76 & 0.449 & -6.21742 & 6.805232 & -0.91 & 0.363 \\
\hline CBI_Lending & $-21.15037 * * *$ & 6.25826 & -3.38 & 0.001 & -4.11422 & 2.637188 & -1.56 & 0.121 \\
\hline
\end{tabular}

Notes: level of statistical significance at one of the confidence intervals: $* * *-99 \%, * *-95 \%, *-90 \%$.

Source: compiled by author.

The last studied indicator of the stability of the banking system is the level of its capitalization. The results presented in Table 6 showed that the growth of central bank independence may lead to a decrease in the level of capitalization of the banking system. At the same time, GDP growth is a factor that deepens such a decline, and the concentration of the banking system and external debt can stimulate an increase in the level of bank capitalization.

Table 6 . The results of multiple panel regression modeling of the impact of central banks' independence on banks' capitalization

\begin{tabular}{|l|c|c|c|c|c|c|}
\hline Variable & Coef. & Std. Err. & $\mathrm{t}$ & $\mathrm{P}>|\mathrm{t}|$ & Lowest 95\% & Highest 95\% \\
\hline CBI & $-1.838874 * *$ & 0.7747641 & -2.37 & 0.018 & -3.364458 & -0.31329 \\
\hline Concentration & $0.0842939^{* * *}$ & 0.0191814 & 4.39 & 0.000 & 0.046524 & 0.1220639 \\
\hline Debt & $0.360822^{* * *}$ & 0.0078548 & 4.59 & 0.000 & 0.0206153 & 0.0515491 \\
\hline GDP & $-0.1354586^{* * *}$ & 0.0459216 & -2.95 & 0.003 & -0.2258826 & -0.0450347 \\
\hline Constant & $13.07774 * * *$ & 2.627513 & 4.98 & 0.000 & 7.903916 & 18.25156 \\
\hline
\end{tabular}

Notes: level of statistical significance at one of the confidence intervals: $* * *-99 \%, * *-95 \%, *-90 \%$.

Source: compiled by author.

Note that in terms of developed countries, the independence of the central bank has a positive impact on the stability of the banking system, as measured by the indicator of its capitalization (Table 7). Stimulators of strengthening the banking system are also well-defined goals of the central bank, its independence in the choice of monetary policy instruments. On the other hand, increasing independence from the government in the appointment and performance of central bank CEO may create the preconditions for deteriorating bank capitalization. At the same time, developing countries are showing a decline in the level of bank capitalization, both with the general growth of central bank independence and with the strengthening of such aspects as the independence of monetary policy and restrictions on government lending. At the same time, the defined goals of monetary policy create incentives to improve the capitalization of banks.

Table 7. The results of multiple panel regression modeling of the impact of central banks' independence on banks' capitalization within developed and developing countries

\begin{tabular}{|l|c|c|c|c|c|c|c|c|}
\hline \multirow{2}{*}{ Variable } & \multicolumn{4}{|c|}{ Developed countries } & \multicolumn{4}{c|}{ Developing countries } \\
\cline { 2 - 9 } & Coef. & Std. Err. & $\mathrm{t}$ & $\mathrm{P}>|\mathrm{t}|$ & Coef. & Std. Err. & $\mathrm{t}$ & $\mathrm{P}>|\mathrm{t}|$ \\
\hline CBI & $2.07566^{* *}$ & 0.8690843 & 2.39 & 0.018 & $-4.787093^{* * *}$ & 0.9173467 & -5.22 & 0.000 \\
\hline CBI_CEO & $-8.305862^{*}$ & 4.314085 & -1.93 & 0.056 & -1.864826 & 5.55219 & -0.34 & 0.738 \\
\hline CBI_Goal & $2.057129^{* *}$ & 0.890294 & 2.31 & 0.022 & $8.884472^{* *}$ & 3.388519 & 2.62 & 0.010 \\
\hline CBI_Policy & $35.34626^{* * *}$ & 11.23329 & 3.15 & 0.002 & $-15.06677 * * *$ & 2.936336 & -5.13 & 0.000 \\
\hline CBI_Lending & 6.758544 & 4.622827 & 1.46 & 0.146 & $-6.1964 * * *$ & 1.132128 & -5.47 & 0.000 \\
\hline
\end{tabular}

Notes: level of statistical significance at one of the confidence intervals: $* * *-99 \%, * *-95 \%, *-90 \%$.

Source: compiled by author.

The next stage of assessing the impact of central bank independence on financial stability, as measured by the volatility of the securities market (Table 8), showed no statistically significant effect on the overall sample of countries. At the same time, GDP growth creates conditions for financial stabilization, and the growth of international debt leads to instability.

Table 8. The results of multiple panel regression modeling of the impact of central banks' independence on stock price volatility

\begin{tabular}{|l|c|c|c|c|c|c|}
\hline Variable & Coef. & Std. Err. & $\mathrm{t}$ & $\mathrm{P}>|\mathrm{t}|$ & Lowest 95\% & Highest 95\% \\
\hline CBI & 1.075868 & 1.749634 & 0.61 & 0.539 & -2.368907 & 4.520644 \\
\hline
\end{tabular}


Table 8 (cont.). The results of multiple panel regression modeling of the impact of central banks' independence on stock price volatility

\begin{tabular}{|l|c|c|c|c|c|c|}
\hline Concentration & 0.0458482 & 0.0480712 & 0.95 & 0.341 & -0.0487972 & 0.1404935 \\
\hline Debt & $0.0524759^{* * *}$ & 0.0191698 & 2.74 & 0.007 & 0.0147333 & 0.0902186 \\
\hline GDP & $-0.7967649 * * *$ & 0.1224555 & -6.51 & 0.000 & -1.037862 & -0.5556677 \\
\hline Constant & $16.28835^{* * *}$ & 5.732582 & 2.84 & 0.005 & 5.001731 & 27.57498 \\
\hline
\end{tabular}

Notes: level of statistical significance at one of the confidence intervals: $* * *-99 \%, * *-95 \%, *-90 \%$. Source: compiled by author.

At the level of developed countries, an inverse relationship was found between central bank independence and financial stability (Table 9).

Table 9. The results of multiple panel regression modeling of the impact of central banks' independence on stock price volatility within developed and developing countries

\begin{tabular}{|l|c|c|c|c|c|c|c|c|}
\hline \multirow{2}{*}{ Variable } & \multicolumn{4}{|c|}{ Developed countries } & \multicolumn{4}{c|}{ Developing countries } \\
\cline { 2 - 9 } & Coef. & Std. Err. & $\mathrm{t}$ & $\mathrm{P}>|\mathrm{t}|$ & Coef. & Std. Err. & $\mathrm{t}$ & $\mathrm{P}>|\mathrm{t}|$ \\
\hline CBI & $3.160633^{*}$ & 1.705109 & 1.85 & 0.066 & -3.369553 & 3.722272 & -0.91 & 0.367 \\
\hline CBI_CEO & -5.725785 & 11.46937 & -0.50 & 0.618 & -8.935441 & 21.82418 & -0.41 & 0.683 \\
\hline CBI_Goal & -1.801003 & 2.690098 & -0.67 & 0.504 & $14.88764^{*}$ & 7.96466 & 1.87 & 0.064 \\
\hline CBI_Policy & $8.577115^{* *}$ & 3.497551 & 2.45 & 0.015 & 15.42044 & 10.38853 & 1.48 & 0.141 \\
\hline CBI_Lending & $9.361643^{* *}$ & 3.635018 & 2.58 & 0.011 & -8.549138 & 3.719751 & -2.30 & 0.023 \\
\hline
\end{tabular}

Notes: level of statistical significance at one of the confidence intervals: $* * *-99 \%, * *-95 \%, *-90 \%$.

Source: compiled by author.

Such dependence is primarily determined by the action of such components of the index as the independence of monetary policy and government lending. On the other hand, developing countries showed a statistically significant effect only for the impact of central bank objectives on the stability of the financial system.

\section{Conclusions, Discussion and Recommendations}

The study showed that the independence of the central bank is an important factor in ensuring banking stability. At the same time, the impact on financial stability has not been conclusively confirmed. It should be noted that the stage of development of the country determines the strength of such influence. Thus, developed countries generally show closer links between central bank independence and banking and financial stability, which in most cases are directly dependent, while developing countries have less lasting effects.

It is interesting to analyze the relationship between certain aspects of central bank independence and the level of banking and financial stability. Thus, for developed countries, the most important aspects of central bank independence in the context of banking stability are the goals of the central bank, its independence in choosing monetary policy instruments and, in some cases, limitations of government credit. At the same time, the increase in the independence of the CEO often leads to the opposite effect, causing deterioration in the values of the studied indicators. At the same time, for developing countries, the most important thing is to prioritize the central bank's goals. Thus, the study not only confirmed the positive role of central bank independence in ensuring banking and financial stability, but also justified the sequence of actions aimed at strengthening the independence of the central bank in this context. Thus, in developing countries, the focus should be on defining and prioritizing central bank goals, while developed countries should take a deeper approach to this issue and ensure the independence of monetary policy instruments and financial independence of the central bank.

\section{References}

1. Afshari Z., Daraei F. (2018). The Impact of Central Bank Independence on Stock Market Volatility. Journal of Money and Economy, 13(4), 423-441. Retrieved from: http://jme.mbri.ac.ir/article-1-443-en.html

2. Andrieș A., Podpiera A. (2018). Central bank independence and Systemic risk contributon. Seminarul de Analiză şi Cercetare Economică Banca Naţională a României, Retrieved from: https://www.bnr.ro/DocumentInformation.aspx?idDocument $=27352 \&$ directLink=1

3. Balls E., Howat J., Stansbury A. (2018). Central Bank Independence Revisited: After the financial crisis, what should a model central bank look like? M-RCBG Associate Working Paper Series, 876137 p. Retrieved from: https://www.hks.harvard.edu/centers/mrcbg/publications/awp/awp67 
4. Buiter W. H. (2012). The Role of Central Banks in Financial Stability: How Has It Changed? Centre for Economic Policy Research Discussion Paper Series, 8780. DOI: 10.1142/9789814449922_0002.

5. Cristea A., Lupua Iu. (2014). The central bank policy between the price stability objective and promoting financial stability. Procedia Economics and Finance, 8, 219-225. Retrieved from: https://cyberleninka.org/article/n/1305205.pdf

6. Crowe C., Meade E. (2007). The Evolution of Central Bank Governance around the World. Journal of Economic Perspectives, 21(4), 69-90. Retrieved from: https://www.aeaweb.org/articles? id=10.1257 ljep.21.4.69

7. Cukierman A., Webb S., Neyapti B. (1992). Measuring the Independence of Central Bank and Its Effect on Policy Outcomes. The World Bank Economic Review, 6(3), 353-398. http://documents.worldbank.org/curated/en/797831468739529187/Measuring-the-independence-of-centralbanks-and-its-effect-on-policy-outcomes

8. Garriga A. C. (2016). Central Bank Independence in the World: A New Dataset. International Interactions 42 (5):849-868. doi: 10.1080/03050629.2016.1188813.

9. Global Financial Development database. The World Bank. Retrieved from: https://databank.worldbank.org/source/global-financial-development

10. Grilli V., Masciandaro D., Tabellini G. (1991). Political and monetary institutions and public financial policies in the industrial countries. Economic Policy, 6 (13), 342-392. Available at: https://www.jstor.org/stable/1344630?seq=1

11. Jacome L. (2001). Legal Central Bank Independence and inflation in Latin America during 1990's. IMF Working Paper. WP01/212. 41 p. Available at: https://www.imf.org/en/Publications/ WP/Issues/2016/12/ 30/Legal-Central-Bank-Independence-and-Inflation-in-Latin-America-During-the-1990s-15509

12. Kawai M., Morgan P. J. (2012). Central Banking for Financial Stability in Asia. ADBI Working Paper, 377. Available at: http://www.adbi.org/workingpaper/2012/08/28/5221.central.banking.financial. stability.asia/

13. .Koziuk V. (2017). Central Bank Independence and Financial Stability: Orthodox and Heterodox Approaches. Visnyk of the National Bank of Ukraine, 239, 6-27. https://doi.org/10.26531/vnbu2017.239.006.

14. Posen A. S. (1995). Declarations Are Not Enough: Financial Sector Sources of Central Bank Independence. Available at: http://www.nber.org/chapters/c11021

15. Rizvanoghlu, I., Nagac, A. (2018). Central Bank independence and economic performance in Caucasus and Central Asian Countries. Journal of Eastern European and Central Asian Research (JEECAR), 5(2), 14. https://doi.org/10.15549/jeecar.v5i2.234.

16. Romelli D. (2018). The Political Economy of Reforms in Central Bank Design: Evidence from a New Dataset. BAFFI CAREFIN Centre Research Paper, 87, 49 p. Available at: https://ideas.repec.org/p/tcd/tcduee/tep0918.html.

17. Sheppard P. (2008). The Components of Central Bank Independence and Their Effects. Undergraduate Economic Review, 4(1), 53 p. Available at: https://digitalcommons.iwu.edu/cgi/viewcontent.cgi? article $=1040 \&$ context $=$ uer

18. Sinclair P. J. N. (2005). Central Banks and Financial Stability. Available at: https://www.researchgate.net/publication/228282646_Central_Banks and_Financial_Stability

19. Smaghi L. B. (2007). Central bank independence: from theory to practice. Available at: https://www.ecb.europa.eu/press/key/date/2007/html/sp070419.en.html

20. Stein J. C. (2011). Central Banking and Financial Stability. Available at: https://www.bancaditalia.it/pubblicazioni/lezioni-baffi/pblecture-10/Central-Banking-and-Financial-StabilityBaffi-Lecture.pdf

21. Tommaso Padoa-Schioppa (2002). Central banks and financial stabiilty: Exploring a land in between. Available at: https://www.ecb.europa.eu/events/pdf/conferences/tps.pdf 